\title{
Török harckocsiveszteségek Észak-Szíriában
}

2 016 decembere óta különböző internetes fórumokon és a YouTube csatornán olyan kép- és videó tartalmak jelentek meg, amelyek a 2016. augusztus 24-én indított Eufráteszi Pajzs fedőnevű török hadműveletben kilőtt harckocsikról és más páncélozott gyalogsági harcjárművekről tudósítanak. A hadművelet hivatalos célja az Iszlám Állam nevű terrorszervezet legyőzése és Rakka város felszabadítása volt. A valódi cél azonban feltehetően annak a megakadályozása lehetett, hogy a keletről előrenyomuló kurd milíciák - miután átkeltek az Eufrátesz folyón és elfoglalták a szíriai Manbidzs tartományt - egyesülhessenek a szíriai Afrin régiót uraló nyugati kurd felkelőkkel, ezzel egybefüggő kurd fennhatóságot létrehozva Törökország déli határán. Mivel a művelet kezdete után az ellenállás érzékelhetően nem csökkent, sőt erősödött, 2016 novemberében a török vezetés $\mathrm{Al}$-Bab város térségébe két harckocsizászlóaljat vezényelt több mint 80 harckocsival, köztük Leopard 2A4 és M-60T típusú harckocsikkal, valamint FNSS IFV páncélozott gyalogsági harcjárművekkel. A harckocsikat elsődlegesen a régió magaslatain, statikus

1. ábra. Irányított páncéltörő rakétával megsemmisített török Leopard 2-es az észak-szíriai Al-Bab térségében

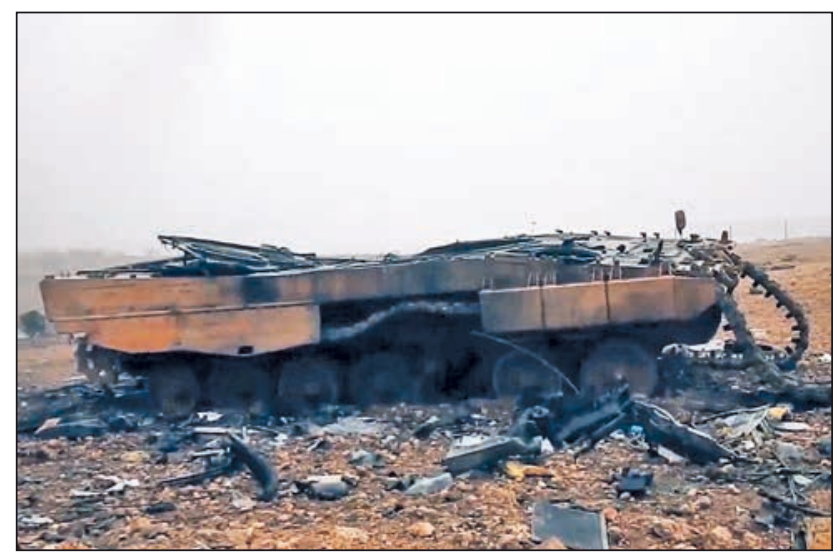

ÖSSZEFOGLALÁS: Törökország a 2016-os Eufráteszi Pajzs fedőnevű hadművelet során az iszlamista és a kurd milíciák ellen kiegészítő páncélvédelem nélküli Leopárd 2A4-es harckocsikat is bevetett. Az Iszlám Állam harcosai tíz napon belül összesen tíz török Leopard 2-es harckocsit és további páncélozott harcjármúveket semmisítettek meg, vagy ejtettek zsákmányul. Tíz feltételezhető ok közül hat az orosz gyártmányú 9K135 Kornet, és az amerikai fejlesztésü TOW-2A páncéltörő-rakétarendszer hatásosságával kapcsolatos.

KULCSSZAVAK: Leopard 2A4 harckocsi, 9K135 Kornet páncéltörő rakéta, TOW-2A páncéltörő rakéta, hőkamerás irányzék, ITAS célfelderítő rendszer, Trophy aktív páncélvédelmi rendszer, AMAP-ADS aktív páncélvédelmi rendszer

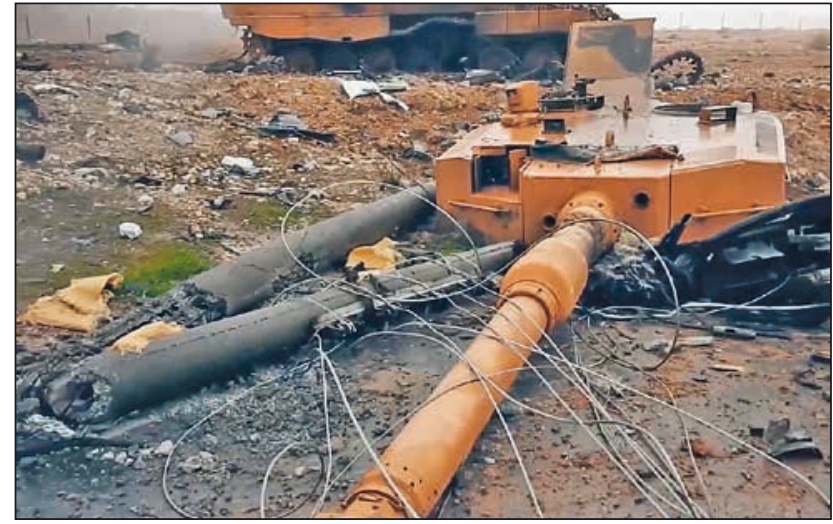

2. ábra. A megsemmisített Leopard 2-es lövegtornya

tüzérségként alkalmazták. Néhány jármű több napig ugyanabban a tüzelőállásban maradt, lehetőséget nyújtva az Iszlám Állam harcosai és a kurd fegyveresek számára, hogy páncéltörő rakétáikkal rejtve, jól álcázott tüzelő pozíciókat foglalhassanak el.

Az iszlamista és a kurd milíciák igen hatásos harckocsielhárító rakétákkal, amerikai gyártmányú TOW-2A, valamint orosz fejlesztésű 9K135-ös Kornet és 9K911-es Fagot irányított páncéltörő rakétákkal rendelkeztek. Jóllehet AlBab város térsége viszonylag nyílt terep, a páncélelhárító csoportok számára azonban az épületromok és törmelékek mögött - a harckocsiktól hátra és oldalirányban mégis elégséges fedezékül szolgált.

Több internetes portálra feltöltött kimutatás szerint 2016 decemberében az Iszlám Állam harcosai tíz napon belül összesen tíz török Leopard 2-es harckocsit és további páncélozott harcjárműveket semmisítettek meg, vagy ejtettek zsákmányul. A tíz kilőtt harckocsi vesztét egyaránt okozták orosz Kornet és amerikai TOW irányított páncéltörő rakéták, amelyek az oldalsó páncélzat átütésével képesek a harckocsik harcképtelenné tételére. Öt járművet páncéltörő rakéta ütött át, három jármű akna- vagy IED-

ABSTRACT: In the course of operation Euphrates Shield in 2016, Leopard 2A4 tanks without auxiliary armour protection were also deployed by Turkey against Islamic and Kurdish militias. Within ten days, warriors of the Islamic State destroyed or captured ten Turkish Leopard 2 tanks in total and additional armoured fighting vehicles. Presumably, 6 out of ten were lost because of the insufficient efficiency of the Russian 9K135 Kornet and the American TOW-2A anti-tank missile systems.

KEY WORDS: Leopard 2A4 tank, 9K135 Kornet anti-tank missile, TOW-2A anti-tank missile, thermal sight, ITAS target acquisition system, Trophy active protection system, AMAP-ADS active protection system

\footnotetext{
Nyá. mérnök alezredes. ORCID: 0000-0002-3732-4573
} 
robbanás miatt, további egy jármű aknavető- vagy rakétatalálat következtében semmisült meg. Egy jármü - amelyet az iszlamisták később felrobbantottak - futóműsérülést szenvedett. Az internetre feltöltött képek tanúsága szerint a páncéltörőrakéta-találatok túlnyomórészt a harckocsilövegtornyok kevésbé páncélvédett oldalát vagy hátulsó részét érték. A rendelkezésre álló képanyag alapján a harckocsi-sérülések elemzését-kiértékelését nehezíti az a körülmény, hogy utólag nem lehet hitelt érdemlően megállapítani, milyen sérüléseket okoztak az elsődleges, és milyeneket a másodlagos - a török légierő, vagy az ISISharcosok általi - behatások. Internetes források tudni vélik, hogy a török légierő utólag bombázott, sőt rakétacsapással teljesen megsemmisített néhány könnyebben sérült Leopard 2-es harckocsit, nehogy az ellenség zsákmányává váljon. Két darab harckocsi holléte tisztázatlan.

Szakmai körökben az Eufráteszi Pajzs hadművelet befejezése óta polemizálnak az Al- Bab környéki Leopard veszteségek okairól. Tíz ok közül hat az orosz gyártmányú 9K135 Kornet (NATO-kódja AT-14 Spriggan) lézersugaras irányítású páncélelhárító-rakétarendszerrel függ össze, amelyet 1994-ben a KBP Instrument Design Bureau vállalat mutatott be. Több mint 15 ország hadseregében rendszeresítették. A Kornet páncéltörő rakétarendszer indítóberendezésből (irányzék-rávezető műszerből, rakétacélzó-, irányzó- és indítószerkezetből), hőkamerás irányzékból, rakétából, valamint rakétaszállító- és indítókonténerből áll, amelyet kétfős kezelőállomány szállít és telepít. Az indító-berendezés Metisz-2-es típusú hőkamerás irányzéka napszaktól független irányíthatóságot biztosít, jóllehet a rendszer hatótávolsága ködben és párás időben $2,5 \mathrm{~km}$-re csökken. A Kornet páncéltörő-rakétarendszer indítószerkezete automatikus töltőszerkezettel kiegészítve könnyen telepíthető szárazföldi, vízi- vagy légi hordozókra. Készletébe kétfajta rakéta, harckocsik és páncélozott járművek ellen 9M133-1 tandem robbanófejes, más kemény célok (például erődítmények) ellen 9M133F-1 termobárikus robbanófejjel szerelt bunkerromboló rakéta tartozik. A tandem robbanófejes rakéta rendkívül hatékony nehéz páncélozott célok ellen. Képes reaktív védelemmel ellátott, 1000-1200 mm-es hengerelt homogén páncélt akár 5500 méter távolságról indítva átégetni. Számos, a YouTube csatornára feltöltött videó bizonyítja, hogy az amerikaiak 2003-as iraki inváziója során az irakiak Kornet rakétákkal amerikai Abrams M1A1 harckocsikat és M2 Bradley páncélozott harcjárműveket semmisítettek meg. A 2006-os izraeli-libanoni háborúban nagyszámú izraeli Merkava harckocsit ért rakétatalálat. A 2014-es gázai konfliktusban Hamasz fegyveresek támadtak Merkavákat Kornet típusú páncéltörő rakétákkal. A 2016-ról 2017-re átnyúló, ezen írás alapgondolatául szolgáló Eufráteszi Pajzs hadmúveletben ISIS harcosok szintén Kornet rakétákkal pusztítottak el török Leopard 2-es harckocsikat és további páncélozott harcjárműveket.

Az Al-Bab környéki páncélos veszteségek másik felelőse az amerikai gyártmányú, huzalvezérlésű TOW-2A páncéltörő-rakétarendszer, amelyet 1980-tól a Hughes Aircraft Company, 1997-től a Raytheon Systems Company gyárt. Egyike a két legszélesebb körben (a világ 45 hadseregében) rendszeresített irányított páncéltörő-rakétafegyvereknek.

A TOW rendszer indítóállványra szerelhető, újrahasználható vetőcsőből, rakétacélzó-, irányzó- és indítóegységből, optikai irányzékból, rakétairányító egységből, akkumulátoros tápegységből, hőkamerából és rakétából áll. Legújabb verzióját ITAS (improved target acquisition system) célfelderítő rendszerrel egészítették ki, amelyhez meggyőző teljesítményű infravörös kamera társul. Az ITAS hőérzékelő segítségével a kezelő akár a 10 km-re lévő jár-

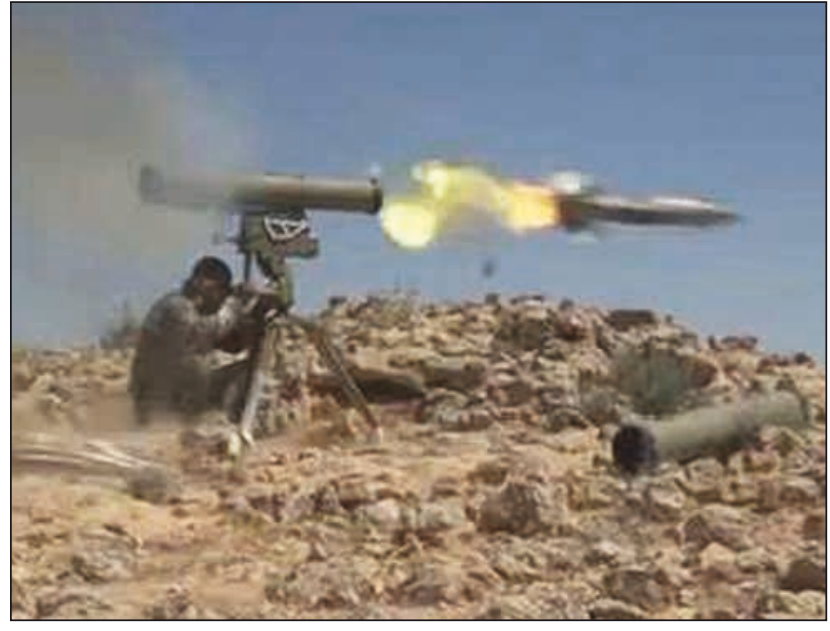

3. ábra. Kornet páncéltörörakéta-indítás hevenyészett fedezékből

műveket is képes észlelni. A rakéta földi indítóállványról, harcjárműről, illetve helikopter-fedélzetről egyaránt alkalmazható. A TOW rendszer harckocsik és páncélozott harcjárművek ellen BGM-71E tandem robbanófejes, más kemény célok (például bunkerek, fedezékek) ellen BGM-71H termobárikus robbanófejjel szerelt rakétákkal van ellátva. A rakéták tandem robbanófeje akár 3750 méter távolságból is képes átütni a reaktív védelemmel ellátott $900 \mathrm{~mm}$ vastag homogén páncélt. Harci hatékonyságát jelzik az iraki-iráni háború, az 1991-es öbölháború, a 2003-as iraki háború, valamint a 2011 óta tartó szíriai polgárháború T-54-es, T-62-es és T-72-es harckocsi-veszteségei.

A török Leopard 2-es harckocsiveszteségek kapcsán szakmai blogok vezetési hiányosságokról, a harckocsik alkalmazásának törökök által elkövetett hibáiról is írnak. Kétséges, hogy az ellenséges páncélosok elleni harcra több mint harminc évvel ezelőtt, még a hidegháború idején kifejlesztett - 60 tonnás Leopard 2-es harckocsik kiegészítő páncélvédelem nélkül alkalmasak-e városharcra, amely egyre gyakoribb napjaink fegyveres konfliktusaiban. Az oroszok például 1994-ben, a csecsen háború idején Grozníjban katasztrofális páncélos veszteségeket szenvedtek el, miután a csecsenek páncéltörő rakétákkal módszeresen kilőtték a harckocsioszlopok első és utolsó járművét, majd megsemmisítették a csapdába rekedt orosz erőket. Médiahírek szerint 24 óra alatt 20 harckocsi és 102 BMP semmisült meg. A 2006-os izraeli-libanoni konfliktusban izraeli források szerint 52 Merkava harckocsi sérült meg, ebből 22-őt lőttek ki Kornet, Metis és RPG-29-es páncéltörő rakétákkal, egyes esetekben a 900 mm-es pán-

4. ábra. Alkalmasan kiválasztott Kornet páncéltörőrakéta-tüzelőállás városharcban

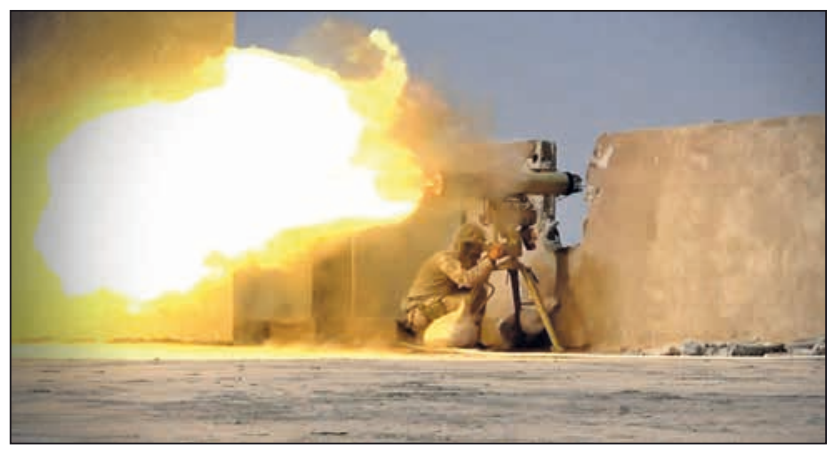




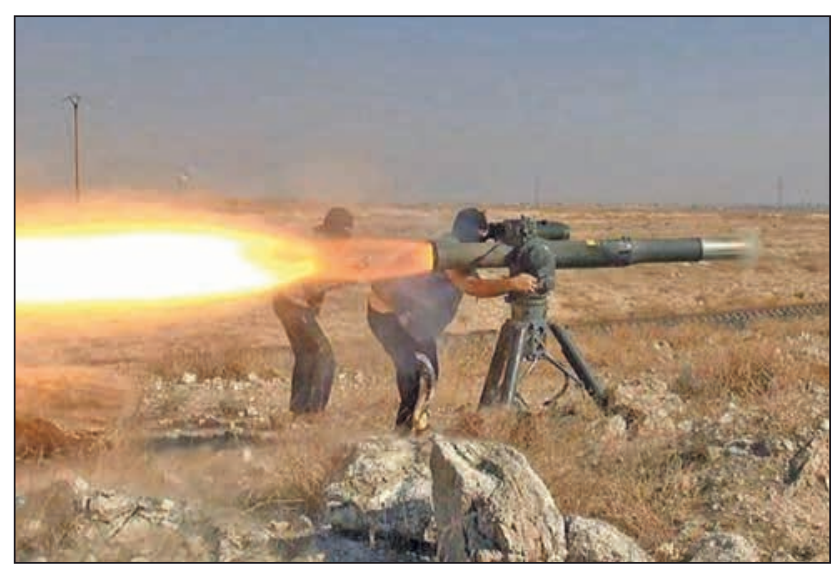

5. ábra. TOW-2-es páncéltörőrakéta-indítás sík terepen

célt is átütve. A Hezbollah harcosok ismerhették, melyek a Merkavák páncélzatának gyenge pontjai.

A páncéltörő rakéták meglepő eredményessége és az a körülmény, hogy a kumulatív hatású lövedékek átütő képessége az ezredfordulóra annyira megnőtt, hogy az páncélvastagság növeléssel már nem volt ellensúlyozható, extra lökést adott az aktív páncélvédelmi rendszerek fejlesztésének. Tény, hogy a szovjet-orosz fejlesztéseket alapul véve Izrael, az Egyesült Államok, Oroszország és Németország felgyorsította saját hard kill aktív védelmi rendszerei kifejlesztését és rendszerbe állítását. Izrael Trophy, illetve Iron Fist névre, az USA Quick Kill-re, Oroszország Aréna-E-re, Németország AMAP-ADS-re keresztelte saját rendszereit. Az izraeli fejlesztések eredményeként 2009 óta az izraeli Merkava IV harckocsik már hatásos Trophy hard kill aktív páncélvédelmi rendszerrel ellátva gördülnek le a gyártósorokról. Ez a lövegtoronyba integrált, a harckocsi körül félgömb alakú védőburkot képező védelmi rendszer radarokból, tűzvezető számítógépből és a torony kerületére szerelt védőtöltet-kivető egységekből áll. A radarok munkáját infravörös érzékelők segítik, amelyek detektálják az ellenséges páncéltörő rakéta (vagy gránát) indítását, és aktiválják a védelmi mechanizmust. A tűzvezető számítógép azonosítja a célt, repülési paraméterei alapján meghatározza az elfogási pont helyét, majd kivet egy repesztöltetet az elfogási pont irányába repülő cél elé. A töltet felrobbanásakor keletkező sűrü repeszfelhőben a rakéta robbanófeje a harckocsitól mintegy 10-30 méter távolságban megsemmisül, vagy átütőereje lényegesen lecsökken. Persze ezzel egy időben a harckocsi közelében

\section{6. ábra. Gépjármúplatóra szerelt TOW-2-es páncéltörőraké-} ta-állvány

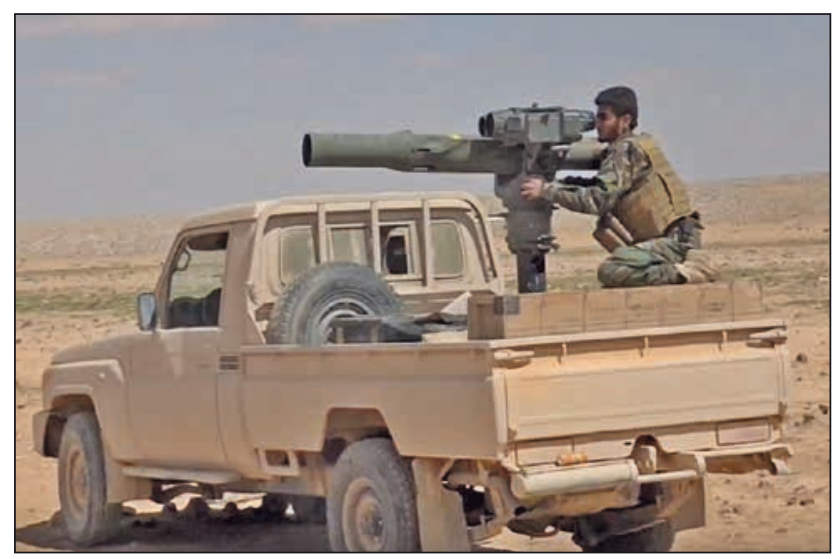

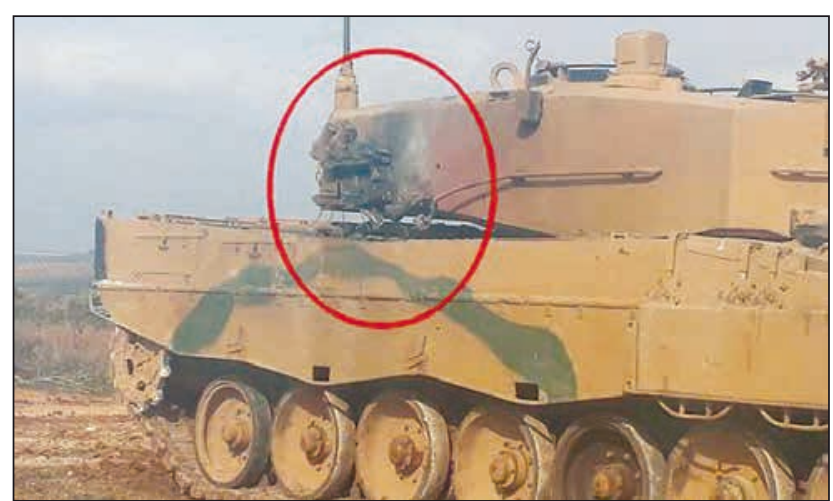

7. ábra. Ezt a kiegészítő páncélvédelem nélküli Leopard 2-est a torony hátsó részén érte a rakétatalálat, de kisebb sérüléssel múködőképes maradt

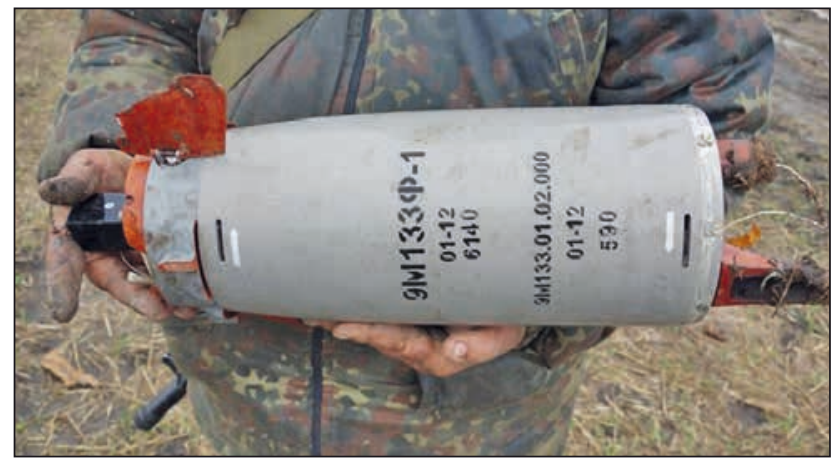

8. ábra. Termobárikus robbanófejjel szerelt, fel nem robbant Kornet rakéta

tartózkodó katonák közül akár 20 fő is megsebesülhet, vagy meghalhat. (Városharc során alig elképzelhető ugyanis, hogy abban kizárólag páncélos eszközök, azaz harckocsik, vagy páncélozott harcjárművek vegyenek részt, tényleges gyalogsági fedezet nélkül.)

A fejlesztések és korszerüsítések hatékonyságának mindenkori fokmérői persze a soron következő háborús események. A Hamász és Izrael között 2014 nyarán Gázában kitört fegyveres konfliktus során például az izraeli Merkava harckocsik „Trophy” aktív páncélvédelmi rendszereikkel közel 15 páncéltörő rakétát semmisítettek meg, közülük a legtöbb Kornet és Konkurs típusú volt. (A Trpophy-k radarképernyője azt is kijelezte, honnan indították a rakétákat vagy gránátokat, hogy a harckocsik viszonozhassák a tüzet.)

\section{9. ábra. Merkava IV-es lövegtornyára szerelt Trophy} páncélvédelmi rendszer közeli képe. Balra fent a repesztöltet-kivető egység, középen a négy radarantenna egyike

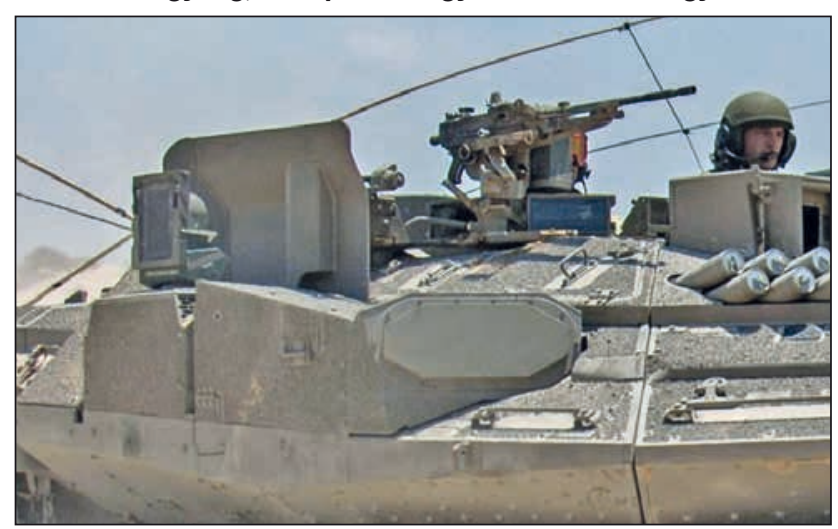


1. táblázat. A 9K135 Kornet páncéltörő rakéta főbb műszaki adatai

\begin{tabular}{|l|c|}
\hline Rakétahosszúság & $1200 \mathrm{~mm}$ \\
\hline Rakétaátmérő & $152 \mathrm{~mm}$ \\
\hline Rakétatömeg & $\begin{array}{c}26 \mathrm{~kg} \text { (konténerrel } \\
\text { együtt } 29 \mathrm{~kg} \text { ) }\end{array}$ \\
\hline Robbanótöltet-tömeg & $4,6 \mathrm{~kg}$ \\
\hline Rakéta-szárnyfesztávolság & $460 \mathrm{~mm}$ \\
\hline Rakétasebesség & $250 \mathrm{~m} / \mathrm{s}$ \\
\hline Rakéta-hatótávolság & $100-5500 \mathrm{~m}$ \\
\hline Elméleti páncélátütő képesség & $1000-1200 \mathrm{~mm}$ \\
\hline
\end{tabular}

\section{2. táblázat. A TOW-2-es páncéltörő rakéta föbb múszaki} adatai

\begin{tabular}{|l|c|}
\hline Rakétahosszúság & $1410 \mathrm{~mm}$ \\
\hline Rakétaátmérő & $152 \mathrm{~mm}$ \\
\hline Rakétatömeg & $22,6 \mathrm{~kg}$ \\
\hline Robbanótöltet-tömeg & $5,9 \mathrm{~kg}$ \\
\hline Rakéta-szárnyfesztávolság & $460 \mathrm{~mm}$ \\
\hline Rakétasebesség & $278-320 \mathrm{~m} / \mathrm{s}$ \\
\hline Rakéta-hatótávolság & $65-3750 \mathrm{~m}$ \\
\hline Páncélátütő képesség & $900-1020 \mathrm{~mm}$ \\
\hline
\end{tabular}

3. táblázat. A Leopard 2A4-es föbb múszaki jellemzői

\begin{tabular}{|l|c|}
\hline Tömeg & $55,4-62,5 \mathrm{t}$ \\
\hline Hosszúság & $9,67 \mathrm{~m}$ \\
\hline Szélesség & $3,77 \mathrm{~m}$ \\
\hline Magasság & $2,64 \mathrm{~m}$ \\
\hline Motor & MTU MB 873 diesel \\
\hline Motorteljesítmény & $1100 \mathrm{~kW}$ \\
\hline Maximális sebesség & $72 \mathrm{~km} / \mathrm{h}$ \\
\hline Hatótávolság & $450 \mathrm{~km}$ \\
\hline Páncélzat & $\begin{array}{c}\text { Harmadik generációs } \\
\text { négyrétegű Chobham } \\
\text { kompozit páncél }\end{array}$ \\
\hline Fegyverzet & $\begin{array}{c}120 \text { mm-es sima csövű } \\
\text { ágyú és két darab } \\
7,62 \text { mm-es MG3 } \\
\text { géppuska }\end{array}$ \\
\hline
\end{tabular}

A DSR Technologies és az izraeli Rafael Advanced Defense Systems együttműködésének eredményeként, 2014ben az amerikai hadsereg megkezdte a Trophy páncélvédelmi rendszer (és könnyített változata) kipróbálását. Azóta számtalan Trophy rendszerrel ellátott Abrams harckocsi és Stryker páncélozott szállító harcjármű tűnik fel internetes videókon. Úgy tűnik, az Egyesült Államok szárazföldi haderőneme lesz a második Trophy felhasználó a világon.

A Business Insider Deutschland internetes oldalon, 2018 márciusában közölt információ szerint - feltehetően az észak-szíriai Al-Bab város környéki harcokban kiegészítő páncélvédelem hiánya miatt elszenvedett Leopard 2-es veszteségek miatt - a török felső vezetés úgy döntött, hogy a német Rheinmatall vállalattól első ütemben 100 darab Leopard 2-esre AMAP-ADS (a Trophy-nál állítólag korszerübb) aktív páncélvédelmi rendszert szerez be. Az AMAP-ADS Svédországban AAC, Franciaországban Shark néven ismert. Még nincs adat az árról, amely valószínűsíthetően egy közepes, kétszámjegyű milliós tétel lehet.

\section{FORRÁSOK}

Er galt als unzerstörbar: In Syrien ging offenbar der Leopard-Mythos ...

https://www.focus.de/.../schwachstelle-entdeckt-verlustein-syrien-ein-;

Leopard in Syrien: Deutschlands Vorzeigepanzer unterliegt im Kampf ...

www.faz.net > Politik > Ausland;

Panzerverluste in Nordsyrien - Lessons Learned von Rolf Hilmes

Europäische Sicherheit \& Technik Februar 2018;

Syrien: Leopard-2-Verluste kratzen am deutschen Panzer-Mythos ...

https://www.welt.de , Wirtschaft

Darum werden so viele Panzer in Syrien und Irak abgeschossen ...

https://www.stern.de/.../darum-werden-so-viele-panzerin-syrien-und-:

Syrien: Zehn deutsche Panzer in Al-Bab verbrannt Sputnik ...

https://de.sputniknews.com/.../20161227313942932syrien-tuerkei-p;

Bewertung der türkischen Leopard 2 - Verluste in Nordsyrien

https://www.panzertruppe.com/.../nr-56-2017.html? ...;

AT-14 (Spriggan) / 9M133 (Kornet) Anti-Tank Guided Missile (ATGM ...

https://www.militaryfactory.com/smallarms/detail. asp?smallarms_id.;

The Better Wiki - 9M133 Kornet

https://thebetter.wiki/en/9M133_Kornet;

TOW-2A vs. T-90: Detailed Analysis - SouthFront https://southfront.org/tow-2a-vs-t-90-detailed-analysis/; US produced TOW 2A ATGWs in Syria - Armament Research Services

armamentresearch.com/us-produced-tow-2a-atgws-in-syria/; Schutzsystem für Leopard-Panzer: Nicht nur Erdogan will es - DBwV

https://www.dbwv.de/.../schutzsystem-fuer-leopardpanzer-nicht-nur-:

9M133 Kornet - IPFS

https://ipfs.io/ipfs/.../wiki/9M133_Kornet.html;

Merkava : Battle Royale 2006 - Had- és rendvédelem-história, kicsit ...

lemil.blog.hu/2014/05/12/merkava_battle_royale;

anti-tank guided missile (USA) - BGM-71 TOW - Military Periscope

https://www.militaryperiscope.com/mdb-smpl/.../ w0003228.shtml;

TOW 2 (Panzerabwehrlenkwaffe) - Deutsches Heer www.deutschesheer.de/;

Somkuti Bálint: Groznij két ostroma - biztonsagpolitika.hu old.biztonsagpolitika.hu/.../1336342971_SOMKUTI_Balint_Groznij_ket_ostroma;

Erdoğan will unbedingt eine bestimmte Waffentechnik aus .. https://www.businessinsider.de/erdoan-will-unbedingteine-bestimmte. 